\title{
The Role of the Liver in the
}

\section{Metabolism of Vitamin D}

\author{
G. Ponchon and H. F. DeLuca
}

From the Department of Biochemistry, University of Wisconsin, Madison, Wisconsin 53706

A B S T R A C T The metabolism of vitamin $\mathrm{D}_{3}$ has been studied after intravenous injection of $10 \mathrm{IU}$ of $\left[1,2{ }^{3} \mathrm{H}\right]$ vitamin $\mathrm{D}_{3}$ to vitamin $\mathrm{D}$-deficient rats. The disappearance of the radioactivity from the plasma follows a very peculiar pattern characterized by an early rapid disappearance followed by a rebound of radioactivity before assuming still a third rather slow disappearance rate. The "rebound" phenomenon is concomitant with a rapid release of the radioactivity from the liver and is accounted for by the appearance of 25-hydroxycholecalciferol and other metabolites in the blood. It is postulated that the liver is the major site of transformation of vitamin $\mathrm{D}_{3}$ into 25-hydroxycholecalciferol.

\section{INTRODUCTION}

There has been much recent investigation into early biochemical events after the administration of vitamin $\mathrm{D}$ to man and animals (1). In experiments in man, it was noted that after the intravenous administration of labeled vitamin $\mathrm{D}_{3}$ the plasma radioactivity falls rapidly at first and then "rebounds" before assuming a regular decay curve $(2,3)$. Previously this had not been noted in animals. Until now, the origin and significance of this "rebound" remained a matter of speculation. The "rebound" phenomenon has now been demonstrated in rats and is the result of radioactivity leaving predominantly the liver to enter the plasma. This radioactivity is composed primarily of 25-hydroxycholecalciferol, the recently identified metabolite believed to be the metabolically active form of vitamin $\mathrm{D}_{3}(4,5)$. The results further suggest that the liver is the main organ involved in the conversion of vitamin $\mathrm{D}_{3}$ to 25-hydroxycholecalciferol.

The aim of the present study is to investigate the role of the liver in the metabolism of vitamin $D_{3}$ in the rat,

This work was published with the approval of the director of the Wisconsin Agricultural Experiment Station.

Received for publication 17 January 1969 and in revised form 19 March 1969. particularly in respect to the plasma "rebound" and the formation of 25-hydroxycholecalciferol.

\section{METHODS}

Tritiated vitamin $D . \quad\left[1,2-{ }^{3} \mathrm{H}\right]$-vitamin $\mathrm{D}_{3}$ with a specific activity of $24,453 \mathrm{dpm} / \mathrm{IU}$ or $0.44 \mu \mathrm{c} / \mu \mathrm{g}$ was prepared in this laboratory as reported earlier (6). Radiochemical purity, achieved through column chromatography on silicic acid, was assessed by chromatographic methods and ultraviolet spectrophotometry (6). The labeled vitamin $D_{3}$ was dissolved either in absolute ethanol or in plasma from vitamin-D deficient rats at a concentration of $200 \mathrm{IU} / \mathrm{ml}$.

Animals. Holtzman, male weanling rats housed in individual hanging wire cages were fed for 2-3 months the vitamin D-free diet No. $11(0.47 \% \mathrm{Ca}, 0.30 \% \mathrm{P})$ described by Guroff, DeLuca, and Steenbock (7). At the time of experiments, the rats weighed an average of $230 \mathrm{~g}$ and were vitamin $\mathrm{D}$ deficient as revealed by a lack of growth and low serum calcium values.

Experimental procedure. In the first series of experiments, the disappearance of the plasma radioactivity was investigated after intravenous injection of labeled vitamin $\mathrm{D}_{3}$ (series I). Doses of $10 \mathrm{IU}\left[1,2{ }^{3} \mathrm{H}\right]$-vitamin $\mathrm{D}_{3}$ in 0.05 $\mathrm{ml}$ plasma were injected into the jugular vein of 13 rats under light ether anesthesia. The animals were placed in individual restraining cages (8) during the periods of blood sampling or in their original cages with food (diet No. 11) and water ad lib. $0.4 \mathrm{ml}$ of heparinized blood samples from the tail vein was collected at specific time intervals after dosage. Plasma was separated by centrifugation for radioactivity measurements. Hematocrits were performed on several occasions using heparinized microhematocrit tubes (Yankee, Clay-Adams, Inc., New York). The proportion of the injected labeled vitamin $\mathrm{D}_{3}$ present in the plasma at each time period was obtained by multiplying the radioactivity of the $0.1 \mathrm{ml}$ plasma sample by the estimated plasma volume "P1 V." The total initial blood volume "initial BV" was assumed to represent $6 \%$ of the body weight, and the plasma "initial P1 V" as well as the red blood cell volumes "initial RBC V" were deduced on the basis of the hematocrit value, usually 50 at the beginning of the experiments. Blood and plasma volume estimates were corrected for the blood losses occurring by multiple blood samplings during the experiments. The following calculations were used for these corrections: (a) Loss of red blood cells at the time of the first sampling $=$ blood volume subtracted $\times \mathrm{Hct} / 100=$ milliliters of RBC lost. (b) This volume of lost $\mathrm{RBC}$ was sub- 
tracted from the "initial $\mathrm{RBCV}$ " to give the "remaining RBC V." (c) At the beginning of the next blood sampling, knowing the new Hct value, the "remaining P1 V" was given by "remaining RBC V" $\times(100-$ Hct $) /$ Hct. The same calculation was applied to each successive blood sample.

Bile duct cannulations were performed in two rats under ether-pentobarbital (Nembutal, Abbott Laboratories, North Chicago, Ill.) anesthesia. The bile was collected through a polyethylene catheter PE 10 (Intramedic, Clay-Adams, Inc., New York). Blood samples were collected as usual from the tail vein.

In another group of rats (series II), 10 IU of $\left[1,2-{ }^{3} \mathrm{H}\right]-$ vitamin $\mathrm{D}_{3}$ in $0.05 \mathrm{ml} 100 \%$ ethanol was injected intravenously via the jugular vein under light ether anesthesia. Animals were killed by exsanguination through cardiac puncture under ether anesthesia at specific time intervals after dosage. One rat was sacrificed at each time. The plasma was immediately separated by centrifugation from the heparinized blood. The livers and kidneys were removed, rinsed in $0.9 \%$ aqueous $\mathrm{NaCl}$, blotted on adsorbent paper, and weighed. The small intestines were dissected from the mesentery and cut into segments which were rinsed in $0.9 \%$ aqueous $\mathrm{NaCl}$ after all intestinal contents were carefully removed. They were blotted on adsorbent paper and weighed. The femurs were dissected, weighed, and split longitudinally to remove the bone marrow. Samples of striated muscles surrounding the femurs were freed of fat and ligaments, rinsed in $0.9 \%$ aqueous $\mathrm{NaCl}$, blotted on adsorbent paper, and weighed. All plasma and tissue samples were kept frozen at $-10^{\circ} \mathrm{C}$ until use.

Total radioactivities in plasma and tissues of each rat were determined in triplicate (femurs in duplicate). Total plasma volume, skeleton, and striated muscle weights were estimated to represent respectively 3,15 , and $30 \%$ of body weight.

In the last series of experiments (series III) the distribution of radioactivity among vitamin $\mathrm{D}$ and its metabolites in plasma and tissue was studied as a function of time after injection of vitamin $\mathrm{D}_{3}{ }^{3} \mathrm{H}$. Each of 30 rats was injected intravenously with $10 \mathrm{IU}$ of $\left[1,2-{ }^{3} \mathrm{H}\right]$-vitamin $\mathrm{D}_{3}$ in $0.05 \mathrm{ml}$ of plasma from vitamin D-deficient rats. Groups of four rats each were bled and sacrificed as in the previous experiments at various times after vitamin $\mathrm{D}_{3}{ }^{-} \mathrm{H}$ dosage (six rats were killed at $4 \mathrm{hr}$ ). Plasma and livers were collected, and their total radioactivities were measured in triplicate as in series I. In addition, pooled plasma and liver samples from each group of rats were submitted to lipid extraction and chromatography to determine the relative and absolute amounts of unchanged vitamin $\mathrm{D}_{3}$ and its metabolites.

Extraction and chromatography. Lipid extraction in chloroform-methanol was carried out according to the procedure of Bligh and Dyer (9) slightly modified in this laboratory (10). The radioactivities of the "chloroformsoluble," "aqueous-soluble," and "nonextractable" phases were measured in triplicate. The chloroform extracts were dried under $\mathrm{N}_{2}$ and redissolved in $5-10 \mathrm{ml}$ of redistilled Skelly B (petroleum ether, bp $67^{\circ} \mathrm{C}$ ). They were chromatographed on silicic acid columns (reference 11, footnote 1 ) according to the following solvent system. (a) An exponential gradient $0-50 \%$ diethyl ether in redistilled Skelly B was first obtained by superimposing a holding chamber containing $250 \mathrm{ml}$ of $75 \%$ diethyl ether in petroleum ether on a $250 \mathrm{ml}$ Erlenmeyer mixing chamber containing $230 \mathrm{ml}$ of $100 \%$ Skelly B. (b) An exponential gradient from $50 \%$ di-

${ }^{1}$ Ponchon, G., and H. F. DeLuca. Data in preparation. ethyl ether in Skelly B to $76 \%$ ether, $21 \%$ Skelly B, and 3\% methanol was next used by adding $200 \mathrm{ml}$ of $5 \%$ methanol in diethyl ether to the empty holding chamber. (c) An exponential gradient from $76 \%$ ether, $21 \%$ Skelly B, and $3 \%$ methanol to $40 \%$ ether, $6 \%$ Skelly $\mathrm{B}$, and $54 \%$ methanol was obtained by adding $150 \mathrm{ml}$ of $100 \%$ methanol to the empty holding chamber. The effluents were collected in $10-\mathrm{ml}$ fractions directly in counting vials for radioactivity measurements.

Radioactivity measurements. $0.1 \mathrm{ml}$ of each plasma sample was pipetted in triplicate into counting vials and dried under an infrared lamp. To the vials were added 1 drop of distilled water and $0.5 \mathrm{ml}$ of "NCS" solubilizer (NuclearChicago Corporation, Des Plaines, Ill) (12). The stoppered vials were then incubated at $40^{\circ} \mathrm{C}$ for $12-24 \mathrm{hr}$ to achieve complete dissolution of the organic matter in the NCS. Toluene counting solution ( $100 \mathrm{mg}$ of dimethyl 1,4-bis[2-(5phenyloxazolyl) ] benzene (POPOP) and $2.0 \mathrm{~g}$ of 2,5-diphenyloxazole (PPO) per liter of toluene analytical reagent was then added to each counting vial.

Total radioactivities in the various tissues were determined in triplicate by the combustion technique of Kelly, Peets, Gordon, and Buyske (13) with a Thomas Ogg Safety Igniter (Arthur H. Thomas Co., Philadelphia, Pa.), as described earlier (6). The resulting tritiated water was dissolved and counted in combustion counting solution $(6 \mathrm{~g}$ of PPO, $5 \mathrm{mg}$ of dimethyl POPOP, $200 \mathrm{ml}$ of absolute ethanol, and toluene to 1 liter).

Aliquots of the chloroform-soluble phases were monitored for radioactivity in toluene counting solution. Aliquots of each aqueous-soluble phase were dried in counting vials, redissolved in distilled water and NCS solubilizer, and mixed with toluene counting solution. The nonextractable radioactivity was obtained by dissolving the residue from the lipid extractions in the NCS solubilizer and counting in toluene counting solution. The chromatographic fractions were dried directly in the counting vials and counted in toluene counting solution. The "dose standards" were measured in triplicate in toluene counting solution after dissolution in NCS solubilizer $\left(\mathrm{D}_{3}-{ }^{3} \mathrm{H}\right.$ in $0.05 \mathrm{ml}$ of plasma).

All radioactivity measurements were performed with a Packard Tri-Carb 3003 liquid scintillation counter equipped with an automatic external standardization system 3951 (14). Counting efficiencies were in the order of $30-35 \%$ with the toluene counting solution and in the order of $15-25 \%$ with the combustion counting solution.

\section{RESULTS}

Plasma radioactivity after i.v. injection of $10 \mathrm{IU}$ of $\left[1,2-{ }^{3} \mathrm{H}\right]$-vitamin $D_{3}$ to vitamin $\mathrm{D}$-deficient rats. (series I). Figs. 1 and 2 show the characteristic pattern of plasma radioactivity after an intravenous dose of tritiated vitamin $\mathrm{D}_{3}$. It may be described as three successive phases.

The initial phase does not last longer than 30 min and consists of a very rapid disappearance of the plasma radioactivity. $51.7 \pm 8.0 \%$ (reference 4 , footnote 2 ) of the dose is present in the plasma compartment $5 \mathrm{~min}$ after injection and only $34.9 \pm 4.1 \%$ (4) after $30 \mathrm{~min}$.

The second phase occurs between $30 \mathrm{~min}$ and $8 \mathrm{hr}$

\footnotetext{
${ }^{2}$ Mean $\pm_{\mathrm{SEM}}$ (number of rats).
} 


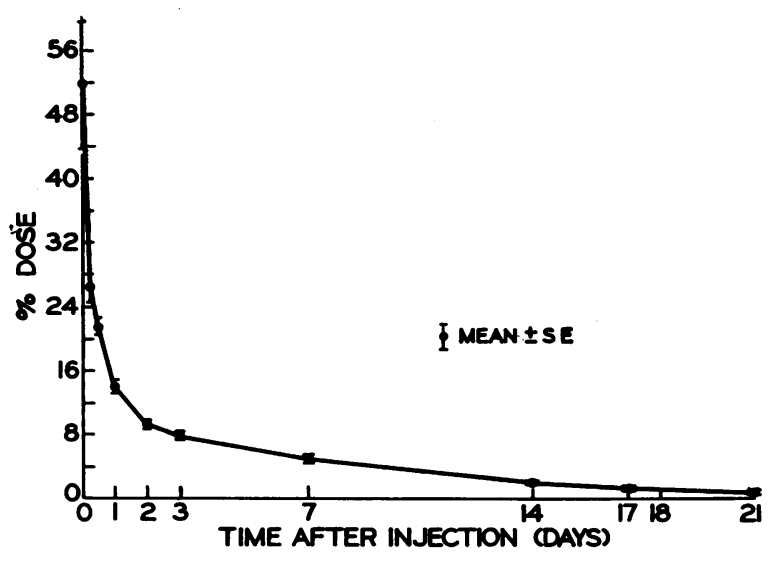

FIgURE 1 Plasma radioactivity after i.v. injection of 10 IU of $\left[1,2-{ }^{8} \mathrm{H}\right]$-vitamin $\mathrm{D}_{3}$ to vitamin $\mathrm{D}$-deficient rats (series I).

and is characterized by a rebound of the plasma radioactivity from a low level of $29.8 \pm 2.8 \%$ (2) at $90 \mathrm{~min}$ to a high of $38.4 \pm 0.6 \%$ (2) at $150 \mathrm{~min}$. The shape of this peak is quite irregular. There are large individual variations in its intensity and time of occurrence.

The third phase is represented by a very slow decline of the plasma radioactivity from $9.4 \pm 0.5 \%(13)$ at 2 days to $0.5 \pm 0.2 \%$ (2) after 3 wk.

The two rats with a bile duct cannulation showed also a rebound of plasma radioactivity between $30 \mathrm{~min}$ and 6 hr after dose, although the radioactivity level was lower (Table I).

Plasma and tissue radioactivity after i.v. injection of $10 \mathrm{IU}$ of $\left[1,2-{ }^{3} \mathrm{H}\right]$-vitamin $\mathrm{D}_{3}$ to vitamin $\mathrm{D}$-deficient rats. (series II). The fraction of the radioactive dose present in plasma and tissues at various times after injection is shown in Fig. 3. The plasma and liver radioactivity curves exhibited a striking "mirror image."

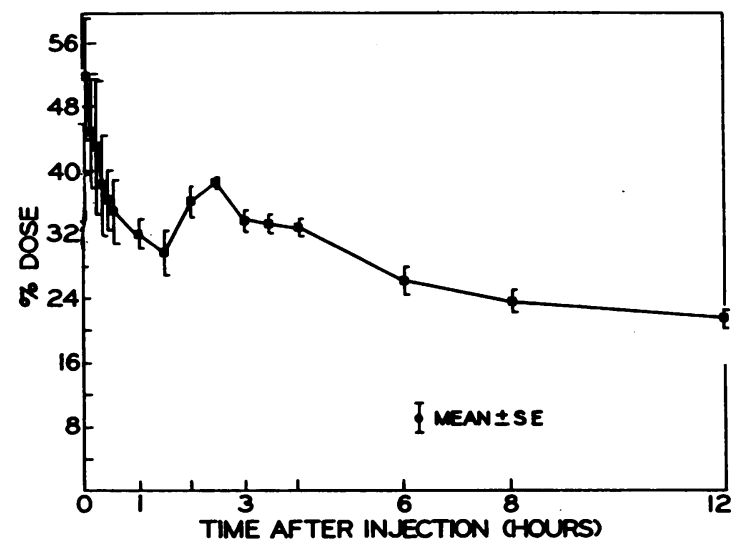

FIGURE 2 Plasma radioactivity after i.v. injection of 10 IU of $\left[1,2-{ }^{3} \mathrm{H}\right]$-vitamin $\mathrm{D}_{3}$ to vitamin $\mathrm{D}$-deficient rats (series I).
TABLE I

Plasma Radioactivity after i.v. Injection of $10 \mathrm{IU}$ of $\left[1,2-{ }^{3} \mathrm{H}\right]$-Vitamin $D_{3}$ to Two Vitamin D-Deficient Rats with Bile Duct Cannulation

\begin{tabular}{rcc}
\hline Time & I & II \\
\hline $\min$ & & \\
30 & - & 21.9 \\
45 & 17.7 & - \\
120 & 23.7 & 28.5 \\
150 & 23.8 & 32.0 \\
180 & 23.6 & 28.6 \\
240 & 23.5 & 29.4 \\
360 & 21.4 & 22.2 \\
\hline
\end{tabular}

Values as per cent of dose in body plasma compartment.

While the liver released most of its radioactive content (from $43.9 \%$ at $90 \mathrm{~min}$ down to $1.4 \%$ at $120 \mathrm{~min}$ ) between $90 \mathrm{~min}$ and $150 \mathrm{~min}$ after an i.v. dose, the plasma radioactivity increased during the same period (from $12.1 \%$ at $100 \mathrm{~min}$ up to $24.6 \%$ at $180 \mathrm{~min}$ ). At the same time the skeleton and muscles were losing some radioactivity, but in much smaller amounts.

From $150 \mathrm{~min}$ on, the liver and to a much smaller extent other tissues reaccumulated radioactivity. Simultaneously, the plasma radioactivity fell to lower levels.

The lower levels of plasma radioactivity observed in this series of experiments as compared to the values given above are undoubtedly due to the ethanol used as vehicle for the injection of the vitamin $\mathrm{D}_{5}-^{8} \mathrm{H}$ instead of plasma. Ethanol was used in this series of experiments before its artifactual effect was established. The importance of the injection solvent in the study of the metabolism of vitamin $\mathrm{D}$ will be reported in another publication (15). The main effect of ethanol is to accel-

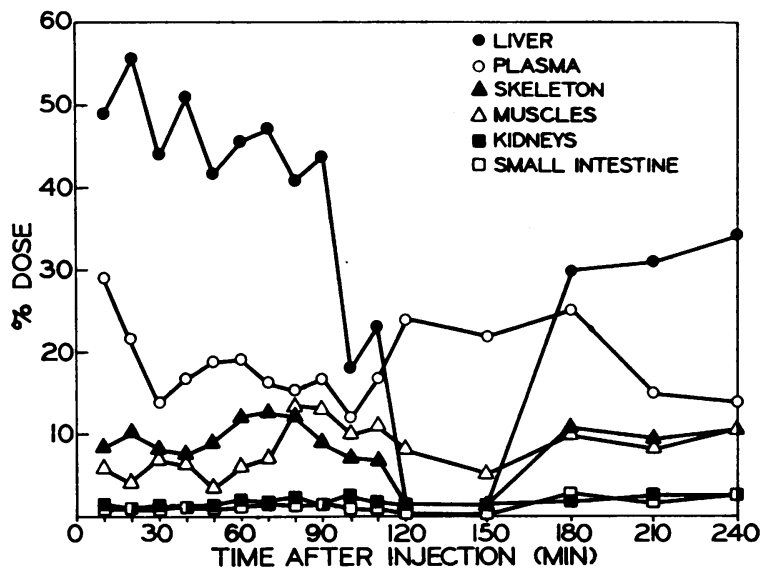

Figure 3 Plasma and tissue radioactivity after i.v. injection of 10 IU of $\left[1,2-{ }^{3} \mathrm{H}\right]$-vitamin $\mathrm{D}_{3}$ to vitamin $\mathrm{D}$-deficient rats (series II). 
TABLE II

Fraction of Dose in Plasma and Liver after i.v. Injection of $10 \mathrm{IU}$ of $\left[1,2-^{8} \mathrm{H}\right]$-Vitamin $\mathrm{D}_{3}$ in Plasma (Series III) to Vitamin D-Deficient Rats

\begin{tabular}{|c|c|c|c|c|c|c|c|}
\hline & \multicolumn{7}{|c|}{ Time after dose } \\
\hline & $15 \mathrm{~min}$ & $30 \mathrm{~min}$ & $2 \mathrm{hr}$ & $4 \mathrm{hr}$ & $6 \mathrm{hr}$ & $24 \mathrm{hr}$ & $48 \mathrm{hr}$ \\
\hline Plasma & $\begin{array}{c}44.5 \pm 2.7 \\
\text { (3) }\end{array}$ & $29.6 \pm 1.8$ & $27.3 \pm 0.3$ & $\begin{array}{c}21.9 \pm 2.0 \\
(6)\end{array}$ & $24.4(2)$ & $18.6 \pm 2.5$ & $10.5 \pm 0.1$ \\
\hline Liver & $35.3 \pm 2.0$ & $41.1 \pm 1.4$ & $20.9 \pm 0.8$ & $\begin{array}{c}30.3 \pm 1.9 \\
(6)\end{array}$ & $19.3 \pm 1.6$ & $5.1 \pm 0.6$ & $6.3 \pm 0.4$ \\
\hline
\end{tabular}

Values expressed as per cent of dose.

Mean $\pm \mathrm{SE}$ (number of rats, if not specified $=4$ ).

Numbers in parentheses $=$ number of rats.

erate the disappearance from the plasma of the vitamin $\mathrm{D}_{8}{ }^{8} \mathrm{H}$ injected i.v. Hence it was decided to rely upon vitamin $\mathrm{D}$-deficient plasma as vehicle for the injection of the labeled vitamin $D_{3}$ in the experimental series $I$ and III.

Distribution of vitamin $D_{3}$ and its metabolites in plasma and liver after i.v. injection of $10 \mathrm{IU}$ of [1,2$\left.{ }^{3} \mathrm{H}\right]$-vitamin $D_{3}$ to vitamin $D$-deficient rats. (series III). The plasma radioactivity disappeared extremely fast during the first period of $30 \mathrm{~min}$, then leveled until $6 \mathrm{hr}$ before assuming a faster disappearance rate (Table II). The apparent absence of rebound is probably due to individual variations in groups of rats killed at each time and to the smaller number of times periods. The liver reached its maximum uptake by $30 \mathrm{~min}$ and lost abruptly half of its radioactivity between $30 \mathrm{~min}$ and $2 \mathrm{hr}$. Afterwards, it reaccumulated some of the dose before the final decrease of radioactivity.

During lipid extraction of plasma and liver most of the radioactivity was soluble in the chloroform phase (Table III). Except at $15 \mathrm{~min}$, around $99 \%$ of the plasma- ${ }^{3} \mathrm{H}$ was chloroform soluble. Liver extracts showed an increased proportion of aqueous-soluble and

TABLE III

Partitioning of Radioactivity During Lipid Extraction of Plasma and Liver (Series III)

\begin{tabular}{|c|c|c|c|c|c|c|c|}
\hline Time........... & $\begin{array}{c}15 \\
\min \end{array}$ & $\begin{array}{c}30 \\
\min \end{array}$ & $\begin{array}{c}2 \\
\mathrm{hr}\end{array}$ & $\begin{array}{c}4 \\
\mathrm{hr}\end{array}$ & $\begin{array}{c}6 \\
\mathrm{hr}\end{array}$ & $\begin{array}{l}24 \\
\mathrm{hr}\end{array}$ & $\begin{array}{l}48 \\
\mathrm{hr}\end{array}$ \\
\hline \multicolumn{8}{|l|}{ Plasma } \\
\hline Chloroform soluble & 91.8 & 99.1 & 97.4 & 99.8 & 95.3 & 99.1 & 97.0 \\
\hline $\left.\begin{array}{l}\text { Aqueous soluble }+ \\
\text { nonextract }\end{array}\right\}$ & 8.2 & 0.9 & 2.6 & 0.2 & 4.7 & 0.9 & 3.0 \\
\hline \multicolumn{8}{|l|}{ Liver } \\
\hline Chloroform soluble & 88.8 & & & 93.3 & & 75.7 & 84.3 \\
\hline Aqueous soluble & 9.6 & & & 3.9 & & 14.3 & 13.0 \\
\hline Nonextract & 1.7 & & & 2.8 & & 10.0 & 2.7 \\
\hline
\end{tabular}

Values are per cent of total sample radioactivity. nonextractable tritium after $24 \mathrm{hr}$. The larger proportion of aqueous-soluble radioactivity seen in plasma and liver at $15 \mathrm{~min}$ might be due to some alteration of the $\left[1,2{ }^{8} \mathrm{H}\right]$-vitamin $\mathrm{D}_{3}$ at the time of injection. The chromatographic patterns of unchanged vitamin $\mathrm{D}$ and its metabolites obtained in plasma and liver after 4 and 48 $\mathrm{hr}$ are shown in Figs. 4 and 5. The major chromatographic fractions were expressed in per cent of chromatographed radioactivity and per cent of dose in Tables IV and V.

In plasma (Table IV), more than $90 \%$ of the radioactivity chromatographed corresponded to unchanged vitamin D (peak III) until 30 min after the i.v. dose. The $6-7 \%$ radioactivity eluted with a retention volume close to peak IV probably represented radiochemical impurities in the $\left[1,2-{ }^{3} \mathrm{H}\right]$-vitamin $\mathrm{D}_{3}$ in plasma since its control chromatography revealed $4.4 \%$ of the dose eluted in an identical position. In sharp contrast was the important proportion of peak IV $(25.6 \%$ of chromatogram) present in the $2 \mathrm{hr}$ plasma extract and rising further to reach $55.3 \%$ of chromatographed radioactivity after $48 \mathrm{hr}$. Expressed as per cent of dose the maximal concentration of peak IV in plasma was reached by $24 \mathrm{hr}$ after dose and decreased afterwards $(9.9 \%$ of dose at $24 \mathrm{hr} ; 5.6 \%$ at $48 \mathrm{hr}$ ). Both at 24 and $48 \mathrm{hr}$, peak IV was the major radioactive vitamin $\mathrm{D}$ metabolite in plasma. Peak V and more polar metabolites made their appearance later than peak IV and accounted for a growing fraction of the radioactivity after $24 \mathrm{hr}$. Peaks I and II never represented an important fraction of the radioactivity in plasma nor did they show any significant change with time. As a consequence of the appearance of peak IV, V, and more polar metabolites, the proportion of unchanged vitamin $\mathrm{D}$ (peak III) decreased consistently from $2 \mathrm{hr}$ on. Its plasma concentration decreased so much that there was less vitamin D than peak IV already at $24 \mathrm{hr}$.

In liver (Table V), the bulk of the radioactivity was represented by unchanged vitamin D (peak III) until 
TABLE IV

Major Chromatographic Fractions in Plasma after i.v. Injection of $10 \mathrm{IU}$ of $\left[1,2-{ }^{3} \mathrm{H}\right]$-Vitamin $\mathrm{D}_{3}$ in Plasma (Series III) into Vitamin D-Deficient Rats

\begin{tabular}{|c|c|c|c|c|c|c|c|c|c|c|c|c|c|c|}
\hline \multirow[t]{2}{*}{$\begin{array}{l}\text { Chromatographic } \\
\text { fractions }\end{array}$} & \multicolumn{2}{|c|}{$15 \mathrm{~min}$} & \multicolumn{2}{|c|}{$30 \mathrm{~min}$} & \multicolumn{2}{|c|}{$2 \mathrm{hr}$} & \multicolumn{2}{|c|}{$4 \mathrm{hr}$} & \multicolumn{2}{|c|}{$6 \mathrm{hr}$} & \multicolumn{2}{|c|}{$24 \mathrm{hr}$} & \multicolumn{2}{|c|}{$48 \mathrm{hr}$} \\
\hline & $\begin{array}{l}\text { \% of } \\
\text { chrom. }\end{array}$ & $\begin{array}{l}\text { \% of } \\
\text { dose }\end{array}$ & $\begin{array}{c}\text { \% of } \\
\text { chrom. }\end{array}$ & $\begin{array}{l}\text { \% of } \\
\text { dose }\end{array}$ & $\begin{array}{c}\text { \% of } \\
\text { chrom. }\end{array}$ & $\begin{array}{l}\text { \% of } \\
\text { dose }\end{array}$ & $\begin{array}{c}\text { \% of } \\
\text { chrom. }\end{array}$ & $\begin{array}{c}\% \text { of } \\
\text { dose }\end{array}$ & $\begin{array}{c}\text { \% of } \\
\text { chrom. }\end{array}$ & $\begin{array}{c}\text { \% of } \\
\text { dose }\end{array}$ & $\begin{array}{c}\text { \% of } \\
\text { chrom. }\end{array}$ & $\begin{array}{c}\% \text { of } \\
\text { dose }\end{array}$ & $\begin{array}{c}\text { \% of } \\
\text { chrom. }\end{array}$ & $\begin{array}{l}\% \text { of } \\
\text { dose }\end{array}$ \\
\hline I & 0 & 0 & 0.2 & 0.06 & 0.2 & 0.05 & 0.6 & 0.1 & 0 & 0 & 1.2 & 0.2 & 0.9 & 0.09 \\
\hline II & 1.7 & 0.7 & 1.0 & 0.3 & 1.5 & 0.4 & 1.4 & 0.3 & 0.6 & 0.1 & 0 & 0 & 0 & 0 \\
\hline III & 92.3 & 39.9 & 91.6 & 26.3 & 72.0 & 19.1 & 57.4 & .12 .2 & 62.7 & 14.8 & 26.1 & 4.7 & 12.4 & 1.3 \\
\hline IV & & & & & & & 36.5 & 7.8 & 33.0 & 7.8 & 54.7 & 9.9 & 55.3 & 5.6 \\
\hline $\mathrm{V}+$ more polar & $6.1^{*}$ & $2.6^{*}$ & $6.9^{*}$ & $2.0^{*}$ & $25.6^{*}$ & * $6.8^{*}$ & & & & & & & & \\
\hline fractions & & & & & & & 3.3 & 0.7 & 3.0 & 0.7 & 15.8 & 2.8 & 28.6 & 2.9 \\
\hline
\end{tabular}

Mean values from pooled samples of four rats.

* Represents IV and V plus more polar fractions.

$6 \mathrm{hr}$ after dose. It was not until $24 \mathrm{hr}$ that peaks IV, $\mathrm{V}$, and more polar metabolites increased significantly. Maximum accumulation of peak IV was reached at 24 hr $(0.8 \%$ of dose), while peaks $\mathrm{V}$ and more polar metabolites were still increasing after $48 \mathrm{hr}$. Note that in contrast to the plasma there was practically as much peak $\mathrm{V}$ and more polar metabolites as peak IV both at 24 and $48 \mathrm{hr}$. Peak I (vitamin D esters) showed a tendency to accumulate slowly in the liver after $24 \mathrm{hr}$. Peak II exhibited no significant changes.

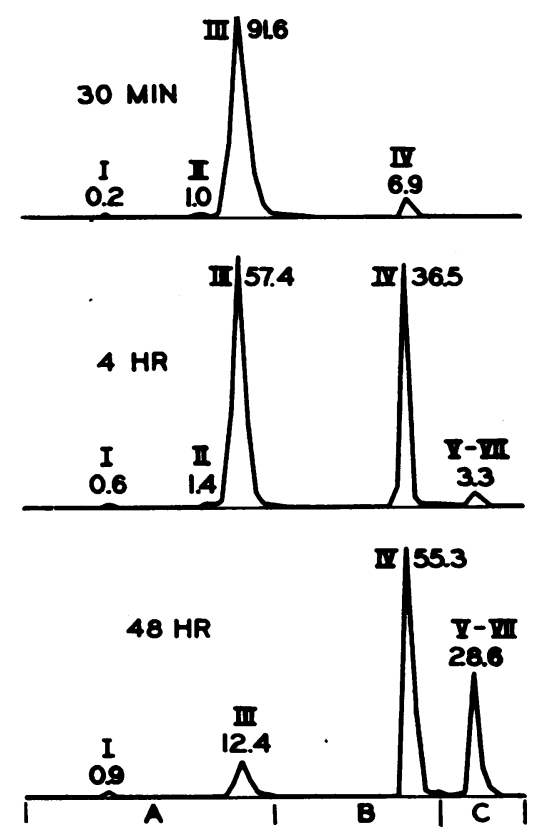

FIGURE 4 Silicic acid column chromatographic profiles of lipid extracts from plasma obtained after i.v. injection of 10 IU of $\left[1,2{ }^{3} \mathrm{H}\right]$-vitamin $\mathrm{D}_{3}$ to vitamin $\mathrm{D}$-deficient rats (series III).

\section{DISCUSSION}

The disappearance of the radioactivity from the plasma of rats given $0.25 \mu \mathrm{g}$ of $\left[1,2-{ }^{8} \mathrm{H}\right]$-vitamin $\mathrm{D}_{\mathbf{z}}$ intravenously showed a very characteristic pattern which may be described in three successive phases.

The first period of very fast disappearance of radioactivity occurred during the first $\mathbf{3 0}$ min after injection. It is probably the result of rapid dilution of the label in the vascular and extravascular spaces combined with an uptake by various tissues such as liver, bones, muscles, kidneys, and small intestine $(6,16)$.

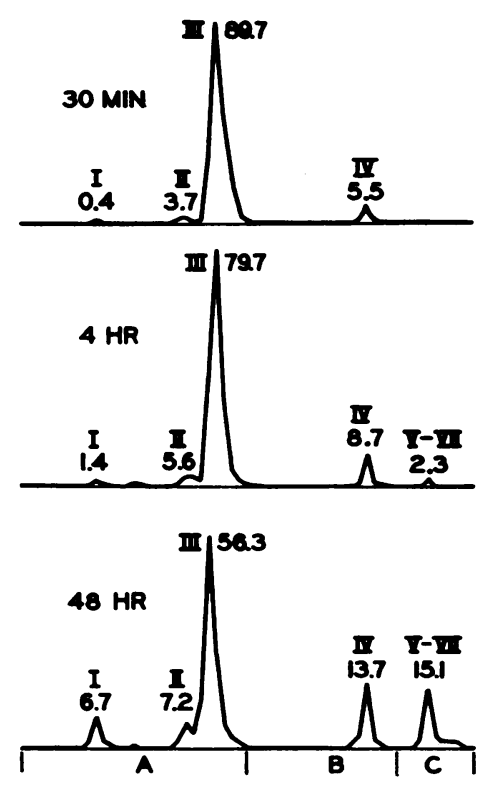

FIGURE 5 Silicic acid column chromatographic profiles of lipid extracts from liver obtained after i.v. injection of 10 IU of $\left[1,2{ }^{3} \mathrm{H}\right]$-vitamin $\mathrm{D}_{3}$ to vitamin $\mathrm{D}$-deficient rats (series III). 
TABLE V

Major Chromatographic Fractions in Liver after i.-v. Injection of $10 \mathrm{IU}$ of $\left[1,2-{ }^{-3} \mathrm{H}\right]$-Vitamin $\mathrm{D}_{3}$ in Plasma (Series III) into Vitamin D-Deficient Rats

\begin{tabular}{|c|c|c|c|c|c|c|c|c|c|c|c|c|c|c|}
\hline \multirow[t]{2}{*}{$\begin{array}{l}\text { Chromatographic } \\
\text { fractions }\end{array}$} & \multicolumn{2}{|c|}{$15 \mathrm{~min}$} & \multicolumn{2}{|c|}{$30 \mathrm{~min}$} & \multicolumn{2}{|c|}{$2 \mathrm{hr}$} & \multicolumn{2}{|c|}{$4 \mathrm{hr}$} & \multicolumn{2}{|c|}{$6 \mathrm{hr}$} & \multicolumn{2}{|c|}{$24 \mathrm{hr}$} & \multicolumn{2}{|c|}{$48 \mathrm{hr}$} \\
\hline & $\begin{array}{c}\text { \% of } \\
\text { chrom. }\end{array}$ & $\begin{array}{l}\text { \% of } \\
\text { dose }\end{array}$ & $\begin{array}{c}\text { \% of } \\
\text { chrom. }\end{array}$ & $\begin{array}{l}\% \text { of } \\
\text { dose }\end{array}$ & $\begin{array}{c}\text { \% of } \\
\text { chrom. }\end{array}$ & $\begin{array}{l}\text { \% of } \\
\text { dose }\end{array}$ & $\begin{array}{c}\text { \% of } \\
\text { chrom. }\end{array}$ & $\begin{array}{l}\% \text { of } \\
\text { dose }\end{array}$ & $\begin{array}{c}\text { \% of } \\
\text { chrom. }\end{array}$ & $\begin{array}{l}\% \text { of } \\
\text { dose }\end{array}$ & $\begin{array}{l}\text { \% of } \\
\text { chrom. }\end{array}$ & $\begin{array}{l}\% \text { of } \\
\text { dose }\end{array}$ & $\begin{array}{c}\text { \% of } \\
\text { chrom. }\end{array}$ & $\begin{array}{l}\text { \% of } \\
\text { dose }\end{array}$ \\
\hline I & 0.4 & 0.1 & 0.4 & 0.1 & 1.0 & 0.2 & 1.4 & 0.4 & 1.0 & 0.2 & 9.9 & 0.4 & 6.7 & 0.3 \\
\hline II & 6.2 & 2.0 & 3.7 & 1.4 & 2.9 & 0.5 & 5.6 & 1.5 & 2.6 & 0.4 & 3.8 & 0.1 & 7.2 & 0.4 \\
\hline III & 88.2 & 28.4 & 89.7 & 33.6 & 87.8 & 16.7 & 79.7 & 22.0 & 89.9 & 15.8 & 50.2 & 2.0 & 56.3 & 2.8 \\
\hline IV & 5.9 & 1.9 & & & 6.0 & 1.1 & 8.7 & 2.4 & 4.1 & 0.7 & 18.9 & 0.8 & 13.7 & 0.7 \\
\hline $\mathrm{V}+$ more polar & & & $5.5^{*}$ & $2.1^{*}$ & & & & & & & & & & \\
\hline fractions & 0 & 0 & & & 1.1 & 0.2 & 2.3 & 0.6 & 1.5 & 0.3 & 13.8 & 0.6 & 15.1 & 0.8 \\
\hline
\end{tabular}

Mean values from pooled samples of four rats.

* Represents IV and V plus more polar fractions.

The second phase exhibited a most intriguing rebound in plasma radioactivity reaching a maximum between 2 and $3 \mathrm{hr}$ after dose. This secondary peak of radioactivity varies with each animal in its timing and intensity. A similar phenomenon has been reported in man and remained so far unexplained $(2,3)$.

Since this rebound occurs in the two rats with bile duct cannulation, we may rule out the possibility of an intestinal reabsorption of radioactive bile products. The same was found by Avioli et al. in three patients with complete biliary fistula (2).

The third period corresponds to a very slow disappearance of plasma radioactivity after 2 days. It is evident that such a slow decrease must be considered in the eventual estimation of the biological half-life of vitamin $\mathrm{D}$ and its metabolites. A calculation based upon the 1st 2 days after injection is likely to give much shorter apparent half-lives than if computed over weeks.

The plasma rebound of radioactivity observed after intravenous injection of labeled vitamin $\mathrm{D}_{3}$ is a prominent feature. It must be due to a shift of the radioactive material from the extravascular, probably intracellular, to the plasma compartment. This prompted us to look for a reciprocal change in the radioactivity of different tissues.

A very definite loss of radioactivity from the liver was found during the plasma rebound occurring between 2 and $3 \mathrm{hr}$ after dose. Although some radioactivity was also lost from the skeleton and muscle, it was clear that the liver was responsible for the major part of the plasma radioactivity rebound by releasing into the blood a large portion of the previously accumulated dose.

Individual rat metabolic variations probably account for some irregularity in the plasma and tissue radioactivity curves. The characteristic pattern was best ob- served by repetitive blood sampling on a single animal rather than by data obtained from groups of rats killed at each time. Ethanol used as a vehicle for injection of the tritiated vitamin in one series of experiments (series II) is responsible for the lower plasma radioactivities when compared to the data obtained after injection of vitamin $\mathrm{D}-{ }^{8} \mathrm{H}$ in plasma vehicle (15).

On the basis of the very high and quick uptake of vitamin $\mathrm{D}$ by the liver $(6,16-18)$ followed by a prompt release of the accumulated dose, it is reasonable to assign an important role to the liver in the early metabolic events of the vitamin. One aspect might be the need to clear the lipoprotein-bound vitamin from the plasma to favor a more specific protein binding (19). However, the vitamin binds readily to its plasma protein carrier before the liver has released much radioactivity, and even when added to serum in vitro (19). Thus the obvious question of what is the nature of the radioactive substance released by the liver into the blood stream was raised. One important possibility is that the released radioactivity represented vitamin D metabolites particularly 25-hydroxycholecalciferol (references 4 and 5 , footnote 1 ) considered to be the active form of vitamin $D$.

Chromatographic data show the appearance of large amounts of 25-hydroxycholecalciferol (peak IV) in plasma at $2 \mathrm{hr}$ after dose. That corresponds with the maximum rebound of plasma radioactivity. Since vitamin $\mathrm{D}_{3}$ (peak III) $(6,11)$ was sharply decreasing, and the other chromatographic fractions were unchanged, the increase in plasma radioactivity must be due to the appearance of 25 -hydroxycholecalciferol. It was during the same time that the liver was losing half of its ${ }^{8} \mathrm{H}$ radioactive content without significant change in its chromatographic profile.

It is interesting to note that the maximum accumula- 
tion of 25-hydroxycholecalciferol (peak IV) in plasma occurred by $24 \mathrm{hr}$, and that most of it was actually produced during the first $4 \mathrm{hr}$. This is particularly relevant to the observation that the earliest physiologic effects of vitamin $\mathrm{D}_{3}$ occur between 10 and $12 \mathrm{hr}$ after an intravenous dose (1) and supports the idea that 25-hydroxycholecalciferol is the active principle of vitamin $\mathrm{D}_{3}$.

More polar metabolites consisting mainly of peak $\mathrm{V}^{1}$ appeared later in plasma and liver. These compounds have not yet been characterized but have been shown biologically inactive. $^{1}$

The conclusion of these observations is that the liver is responsible for the very characteristic rebound of plasma radioactivity occurring around $150 \mathrm{~min}$ after intravenous injection of labeled vitamin $\mathrm{D}_{8}$ to $\mathrm{D}$-deficient rats. The radioactive dose accumulated in the liver during the first $30 \mathrm{~min}$ is partly released into the blood between $30 \mathrm{~min}$ and $4 \mathrm{hr}$. The rebound of radioactivity in the plasma is accounted for by the accumulation of the highly biologically active metabolite, 25-hydroxycholecalciferol. It is further suggested that the liver is the major site of hydroxylation of vitamin $\mathrm{D}_{3}$ (cholecalciferol) into 25-hydroxycholecalciferol. As soon as it is synthesized in the liver cells, 25-hydroxycholecalciferol is released into the plasma.

\section{ACKNOWLEDGMENTS}

This work was supported by grant No. AMO 5800-07 from the U. S. Public Health Service.

\section{REFERENCES}

1. DeLuca, H. F. 1967. Mechanism of action and metabolic fate of vitamin D. In Vitamins and Hormones. R. S. Harris, I. G. Wool, and J. A. Loraine, editors. Academic Press Inc., New York. 25: 315.

2. Avioli, L. V., S. W. Lee, J. E. McDonald, J. Lund, and H. F. DeLuca. 1967. Metabolism of vitamin $\mathrm{D}_{\mathbf{z}}{ }^{8} \mathrm{H}$ in human subjects: distribution in blood, bile, feces, and urine. J. Clin. Invest. 46: 983.

3. Avioli, L. V., F. Williams, J. Lund, and H. F. DeLuca. 1967. Metabolism of vitamin $\mathrm{D}_{\mathbf{3}}{ }^{3} \mathrm{H}$ in vitamin D-resistant rickets and familial hypophosphatemia. J. Clin Invest. 46: 1907.
4. Blunt, J. W., H. F. DeLuca, and H. K. Schnoes. 1968. 25-hydroxycholecalciferol: a biologically active metabolite of cholecalciferol. Chem. Commun. 801.

5. Blunt, J. W., H. F. DeLuca, and H. K. Schnoes. 1968. 25-hydroxycholecalciferol. A biologically active metabolite of vitamin $\mathrm{D}_{3}$. Biochemistry. $7: 3317$.

6. Neville, P. F., and H. F. DeLuca. 1966. The synthesis of $\left[1,2{ }^{8} \mathrm{H}\right]$ vitamin $D_{3}$ and the tissue localization of $0.25 \mu \mathrm{g}$ (10 IU) dose per rat. Biochemistry. 5: 2201.

7. Guroff, G., H. F. DeLuca, and H. Steenbock. 1963. Citrate and action of vitamin D on calcium and phosphorus metabolism. Amer. J. Physiol. 204: 833.

8. Bollman, J. L. 1948. A cage which limits the activity of rats. J. Lab. Clin. Med. 33: 1348.

9. Bligh, E. G., and W. J. Dyer. 1959. A rapid method of total lipid extraction and purification. Can. J. Biochem. Physiol. 37 : 911.

10. Lund, J., and H. F. DeLuca. 1966. Biologically active metabolite of vitamin $\mathrm{D}_{3}$ from bone, liver, and blood serum. J. Lipid Res. $7: 739$.

11. Norman, A. W., J. Lund, and H. F. DeLuca. 1964. Biologically active forms of vitamin $D_{3}$ in kidney and intestine. Arch. Biochem. Biophys. 108: 12.

12. Hansen, D. L., and E. T. Bush. 1967. Improved solubilization procedures for liquid scintillation counting of biological materials. Anal. Biochem. 18: 320.

13. Kelly, R. G., E. A. Peets, S. Gordon, and D. A. Buyske. 1961. Determination of $\mathrm{C}^{14}$ and $\mathrm{H}^{3}$ in biological samples by Shöniger combustion and liquid scintillation techniques. Anal. Biochem. 2: 267.

14. DeWachter, R., and W. Fiers. 1967. External standardization in liquid scintillation counting of homogeneous samples labeled with one, two, or three isotopes. Anal. Biochem. 18: 351.

15. Ponchon, G., and H. F. DeLuca. 1969. Ethanol-induced artifacts in the metabolism of ${ }^{3} \mathrm{H}$-vitamin $\mathrm{D}_{3}$. Proc. Exp. Biol. Med. In press.

16. Norman, A. W., and H. F. DeLuca. 1963. The preparation of $\mathrm{H}^{3}$-vitamins $\mathrm{D}_{2}$ and $\mathrm{D}_{3}$ and their localization in the rat. Biochemistry. 2: 1160.

17. Kodicek, E., E. M. Cruickshank, and D. R. Ashby. 1960. The metabolism of ${ }^{14} \mathrm{C}$-labelled vitamin $\mathrm{D}_{2}$ injected intracardially into rats. Biochem. J. 76: $15 \mathrm{P}$.

18. DeLuca, H. F., M. Weller, J. W. Blunt, and P. F. Neville. 1968. Synthesis, biological activity, and metabolism of $22,23-{ }^{3} \mathrm{H}$-vitamin $\mathrm{D}_{4}$. Arch. Biochem. Biophys. $124: 122$.

19. Rikkers, H., and H. F. DeLuca. 1967. An in vivo study of the carrier proteins of ${ }^{8} \mathrm{H}$-vitamins $\mathrm{D}_{3}$ and $\mathrm{D}_{4}$ in rat serum. Amer. J. Physiol. 213: 380. 